\title{
O NARRADOR LITERÁRIO, A HISTÓRIA ARGENTINA E AS VIDAS DO GENERAL PERÓN
}

\author{
THE LITERARY NARRATOR, THE ARGENTINEAN \\ HISTORY AND THE LIVES OF GENERAL PERÓN
}

\author{
André Luis Mitidieri* \\ Flávia Dantas Rodrigues ${ }^{* *}$ \\ Letícia Batista Guimarães ${ }^{* *}$
}

\begin{abstract}
RESUMO
No presente trabalho, consideramos Las vidas del general, recompilação de artigos do jornalista e escritor argentino Tomás Eloy Martínez (2004), e analisamos as relações entre biografia, história e narrativa. Os textos aqui abordados, que integram essa edição - "Días de exilio en Madrid" (p. 171-178), "Ascenso, triunfo, decadencia y derrota de José López Rega" (p. 179-188), "El miedo de los Argentinos" (p. 189-208) e "Perón y los nazis" (p. 209-238) - fornecem um panorama das décadas durante as quais a Argentina se fez marcar pelo populismo e pelo autoritarismo (1940-1980). Além disso, nesses artigos, as intersecções com o gênero biográfico ou com narrativas de aspecto biográfico juntam-se à voz autobiográfica de Martínez. Dessa maneira, ao apresentar Perón em suas memórias e em estilhaços biográficos, o autor transita entre a historiografia e a narrativa literária, viabilizando dois modos de representar a Argentina: o silêncio da história e o desejo da fazer a história.
\end{abstract}

Palavras-chave: Biografia. História argentina. Las vidas del general. Narrativa literária. Tomás Eloy Martínez.

\begin{abstract}
This paper aims at analyzing the relations among biography, history and narrative in the book Las vidas del general, collection of articles written by the Argentinean journalist and fiction writer Tomas Eloy Martinez (2004). The texts of the quoted book here studied, "Días de exilio en Madrid" (p. 171-178), "Ascenso, triunfo, decadencia y derrota de José López Rega" (p. 179-188), "El miedo de los Argentinos" (p. 189-208) y "Perón y los nazis" (p. 209-238) provide an overview of Argentina during the decades marked by populism and authoritarianism (1940-1980). These articles also are intersected by the biographical genre or with narratives characterized for presenting biographical aspects as well as by the autobiographical voice of Martinez. Thus, introducing Peron from own memoirs of this South American politician and from biographical remembrances others
\end{abstract}

\footnotetext{
“Professor do Curso de Letras/Português-Espanhol da Universidade Estadual de Santa Cruz (UESC, Ilhéus, Bahia). Docente efetivo no Programa de PósGraduação em Letras - Mestrado em Linguagens e Representações - nessa instituição. Docente-colaborador no Mestrado em Literatura Comparada da Universidade Regional Integrada do Alto Uruguai e das Missões (URI-FW).

${ }^{*}$ Graduada em Letras/Português-Espanhol, pela Universidade Estadual de Santa Cruz (UESC, Ilhéus, Bahia). Bolsista do Programa de Iniciação científica da UESC, com apoio da Fundação de Amparo à Pesquisa do Estado da Bahia (FAPESB). Discente no PPGL da UESC: Mestrado em Linguagens e Representações. *** Graduada em Letras/Português-Espanhol, pela Universidade Estadual de Santa Cruz (UESC, Ilhéus, Bahia). Bolsista do Programa de Iniciação Científica (PIBIC/UESC), com apoio do Conselho Nacional de Desenvolvimento Científico e Tecnológico (CNPQ).
} 
have of him, the author operates a transit between historiography and literary narrative, putting into action in his narratives two ways of representing his country: the silence of History and the desire of making History.

Keywords: Argentinean history. Biography. Las vidas del General. Literary narrative. Tomás Eloy Martínez.

Centramos atenção no livro do ficcionista e jornalista argentino Tomás Eloy Martínez, Las vidas del general: memorias del exilio y otros textos sobre Juan Domingo Perón (2004), situando-o neste primeiro momento como indicativo das formas por intermédio das quais pode ocorrer a transtextualidade, ou seja, a maneira pela qual se viabiliza a possibilidade de um texto escapar a uma singularidade que muitas vezes se torna insatisfatória a seu deciframento ou a sua compreensão, exigindo, pois, que sejam consideradas as relações, cifradas ou expressas, com outros textos e textualidades (Cf. Genette, 1989). A transtextualidade ocorre de diferentes modos: 1) pela intertextualidade, uma relação de copresença entre dois ou mais textos, ou seja, a presença efetiva de um texto em outro; 2) pelas relações com os paratextos: títulos, subtítulos, intertítulos, prefácios, epílogos, advertências, prólogos etc., notas à margem, notas de pé de página, finais, epígrafes, ilustrações etc.; 3) pela metatextualidade, relação geralmente denominada comentário, unindo um texto a outro texto que fala dele sem citá-lo e inclusive, no limite, sem nomeá-lo; é por excelência a relação crítica; 4) arquitextualidade: articula uma menção paratextual (subtítulos e títulos, como em Poesias, Ensaios etc.); 5) hipertextualidade: responsável por unir um texto $\mathrm{B}$ (hipertexto) com um texto anterior A (hipotexto), no qual se enxerta de uma maneira distinta à do comentário.

Las vidas del General: memorias del exilio y otros textos sobre Juan Domingo Perón (Martínez, 2004) é uma reedição, com acréscimo e modificações, da antologia que o autor havia publicado na década anterior: Las memorias del General (Martínez, 1996). Esses livros, compostos por artigos jornalísticos, (auto)biográficos e memorialísticos, assim como os romances La novela de Perón (Martínez, 1985) e Santa Evita (Martínez, 1995), constituem hipertextos de um hipotexto chamado Las memorias del semanario Panorama, gravadas por Martínez durante quatro dias, e previamente ditadas pelo general Juan Domingo Perón a seu mordomo e secretário particular, José López Rega. Publicadas na revista argentina Panorama a 14 de abril de 1970, essas "memórias" englobam os 50 primeiros anos da vida do ex-presidente argentino. No mesmo periódico, mas aos dias 21 e 28 de abril, o jornalista edita fragmentos relacionados a elas: sobre Evita e a morte do sindicalista Augusto Vandor, bem como um compêndio das ideias de Perón acerca do que este denominava "a liberação dos povos".

Insatisfeito com as lacunas encontradas no discurso do ex-presidente argentino, o jornalista procede a investigações e à reconstrução de diálogos, reelaborando o que nomeia como "desmemorias" no capítulo "Las memorias de Puerta de Hierro" (p. 13122) que, acompanhado de respectivos documentos, integra Las memorias del general (Martínez, 1996). O texto completo, contudo, é republicado ao final do livro como "Las memorias del semanario Panorama" (Martínez 1996, p. 195-218). A mesma coletânea antes referida passa a ser intitulada Las vidas del General: memorias del exilio y otros textos sobre Juan Domingo Perón (Martínez, 2004). No prefácio a essa nova edição (p. 9-15), o autor considera que o título recente lhe parece mais apropriado por refletir não apenas os relatos com os quais Perón desejou inserir-se na história, mas também os outros relatos dissidentes que completam ou contradizem tal imagem (p. 11).

As relações intertextuais e paratextuais ora vistas, aliadas às contracapas de ambas as edições das antologias, instauram consideráveis mudanças que se reiteram na relação arquitextual a partir do momento em que o autor substitui a palavra "memorias" (constante na edição de 1996) pelo termo "vidas" no título do livro que lança a público em 2004. O subtítulo dessa publicação - "memorias del 
exilio y otros textos sobre Juan Domingo Perón", figurando em sua página de rosto, configura-se simultaneamente como um procedimento arquitextual e paratextual que parece fazer mais jus ao caráter plural das identidades no mundo contemporâneo. Como professor de literatura em universidades norte-americanas, Martínez não ignora os desenvolvimentos teóricos acerca desse tema. Por seu turno, as relações arquitextual, hipertextual, intertextual e paratextual são elas mesmas indicativas da relação metatextual, quer dizer, da forma crítica como o autor encaminha seus textos ao leitor.

A título de exemplo, o subtítulo de Las vidas del general (Martínez, 2004), além das (des)memórias de Perón, anuncia outros trabalhos que, voltados à Argentina populista e ditatorial, revelam, ainda que por fragmentos, um amplo cenário psicossocial. Nesse caso, os artigos "Días de exilio en Madrid" (p. 171-178) e "Ascenso, triunfo, decadencia y derrota de José López Rega" (p. 179-188) trazem histórias cotidianas do exílio de Perón e sua extravagante relação com "El Brujo" López Rega. Por sua vez, "El miedo de los argentinos" (p. 189-208) consiste em testemunho pessoal que, editado com alterações, retoma o texto antes publicado como suplemento de um jornal de Buenos Aires, mostrando os temores da sociedade rioplatense com a situação de terror e violência vivida na década de 1970. Já "Perón y los nazis" (p. 209-238) alude aos vínculos do general e do peronismo com criminosos de guerra croatas e nazistas, acolhidos na Argentina depois da Segunda Guerra Mundial.

Antes de abordar os mencionados textos, necessitamos considerar que o peronismo nasceu após o golpe de Estado de 1943 como um "movimento populista autoritário, fortemente assinalado pelo pensamento social católico, pelo nacionalismo, pelos princípios orgânicos do corporativismo mediterrâneo e pela tradição dos caudilhos da sociedade criolla argentina" (Crassweller, 1988, p. 248). ${ }^{1}$ Por volta de 1946, os peronistas haviam ultrapassado quase por completo

\footnotetext{
${ }^{1}$ Todas as traduções aqui realizadas são de nossa autoria. Valendo-nos do mesmo procedimento a seguir adotado, transcrevemos em nota de rodapé os fragmentos que ora utilizamos dos textos-fonte: "movimiento populista autoritario, fuertemente teñido por el pensamiento social católico, por el nacionalismo, por los principios orgánicos del corporativismo mediterráneo y por la tradición de los caudillos de la sociedad criolla argentina".
}

os socialistas e os comunistas como mensageiros das classes trabalhadoras urbanas. Criando algo novo na política nacional, eles haviam "consolidado sua força abandonando as antigas estruturas de poder em favor da classe trabalhadora urbana e preservando as antigas estruturas de poder a favor do setor rural pobre" (Crassweller, 1988, p. 248). ${ }^{2}$ Além de nomear um movimento político-social, o peronismo transformou-se em adjetivo concebido por distintos estudiosos que, entre as décadas de 1940 e 1950, tentaram conceituá-lo:

Quem tivesse travado algum contato com a Argentina e com a produção de seus intelectuais pode confirmar que, nesse país, poucas palavras permitem referências a uma gama tão ampla de sentidos quanto a palavra peronismo. Ela serve para dar nome ao movimento político nascido a meados da década de 1940, identificado com a figura do coronel Juan Perón; para qualificar o período da história argentina que se inicia em 1945 e termina em 1955, abarcando os dez anos de seus dois primeiros governos; para designar o partido político criado por Perón logo após sua vitória nas eleições de 1946 e que até hoje sobrevive com outras denominações; para fazer referência à identidade política daqueles que, desde aquela época, evocam sua figura e a recordação de seus governos a fim de legitimar diferentes posições no campo da política. $\mathrm{O}$ adjetivo peronista também foi utilizado, e até agora ainda serve, para descrever uma doutrina política, um tipo de governo, uma forma de discurso (Neiburg, 1997, p. $14-15$ ). ${ }^{3}$

Os artigos de Las vidas del general: memorias del exilio y otros textos sobre Juan Domingo Perón que aqui estudamos buscam compreender o peronismo depois da derrocada do segundo governo

\footnotetext{
"[...] consolidado su fuerza dejando de lado las viejas estructuras de poder en favor de la clase trabajadora urbana y preservando las viejas estructuras de poder a favor del sector rural pobre".

3 "Quién hubiera tenido algún contacto con la Argentina y con la producción de sus intelectuales puede confirmar que, en ese pais, pocas palabras permiten referencias a una gama tan amplia de sentidos, cuanto la palabra peronismo. Ella sirve para nombrar el movimiento político nascido en meados de la década de 1940, identificado con la figura del coronel Juan Perón; para calificar el periodo de la historia de la Argentina que se inicia en 1945 y termina en 1955, abarcando los diez años de sus dos primeros gobiernos; para designar el partido político creado por Perón luego después de su vitoria en las elecciones de 1946 y que sobrevive hasta hoy con otras denominaciones; para hacer referencia a la identidad política de los que, desde aquella época, evocan su figura y la recordación de sus gobiernos para legitimar diferentes posiciones en el campo de la política. El adjetivo peronista también fue utilizado, y hasta hoy aún sirve, para describir una doctrina política, un tipo de gobierno, una forma de discurso."
} 
de Juan Domingo Perón, sobretudo na década de 1970. Assim, em sua quarta seção, intitulada "Días de exilio en Madrid" (Martínez, 2004, p. 171-178), ressurge, de outro capítulo do mesmo livro - "Las memorias de Puerta de Hierro" (Martínez, 2004, p. 13-73) - uma das figuras mais destacadas no conjunto de toda a obra em análise: José López Rega. Denominado "El Brujo", era ele quem se responsabilizava pela agenda de trabalho do general, que somente depois de aprová-la partia à caminhada matinal que diariamente precedia seu almoço.

$\mathrm{O}$ "Bruxo" ganha breves menções nesse espaço textual, entre as lembranças do exílio do ex-presidente argentino e as descrições de sua residência madrilense, mas protagoniza o artigo da coletânea "Ascenso, triunfo, decadencia y derrota de José López Rega" (Martínez, 2004, p. 179-188), escrito em Caracas e publicado no jornal La Opinión a 22 de julho de 1975, dois dias depois que, obrigado a renunciar de seu cargo no governo argentino, ele partiu ao Rio de Janeiro como embaixador extraordinário da presidenta Isabelita Perón. Executando o retrato biográfico daquele protagonista iletrado, sem talento aparente para a política, a instância autoral inclui, ao começo do texto, a voz autobiográfica do jornalista, que assim declara:

No final de abril de 1975, a Triple A, uma organização parapolicial que era financiada com fundos do Ministério de Bem-Estar Social e que, aparentemente, respondia às ordens de José López Rega, fez explodir uma bomba lança-panfletos em frente ao edifício da editora Abril, na esquina de Paraguai e Leandro N. Alem, Buenos Aires. Os libelos me declararam inimigo da Argentina e me concediam quarenta e oito horas para partir ao estrangeiro. Desobedeci à advertência e tomei somente algumas precauções. Dez dias mais tarde, estourou uma segunda bomba e recebi ameaças mais rotundas no apartamento onde morava e num restaurante onde estava almoçando. Viajei à França, com esperança de retornar em poucas semanas. Sem levar em conta uma fugaz semana de agosto de 1975, posso dizer que demorei nove anos para voltar [...] (Martínez, 2004, p. 181). ${ }^{4}$

\footnotetext{
${ }_{4}$ "A fines de abril de 1975, la Triple A, una organización parapolicial que se financiaba con fondos del Ministerio de Bienestar Social y que, al parecer, respondía a las órdenes de José López Rega, hizo estallar una bomba lanzapanfletos frente al edificio de la editorial Abril, en la esquina de Paraguay y Leandro N. Alem, Buenos Aires. Los libelos me declararon enemigo de la Argentina y me concedian cuarenta y ocho horas para
}

López Rega é apresentado como um rosto anônimo entre aqueles que rodeavam Perón em 1966. Ainda não associado "ao paroquiano das ciências ocultas que vivia em Madri por um ano à procura da aprovação do general para sua difusa doutrina espiritualista, que teceria o iluminismo Rosacruz e a alquimia de Paracelso com os rituais brasileiros de Umbanda" (Martínez, 2004, p. 182), ${ }^{5}$ era conhecido como empregado para tarefas domésticas e editor de uma revista de tiragem limitada, sustentada por avisos de militantes peronistas. Pela memória de Tony Navarro, da Associated Press, o autor-narrador informa que os escritos de dom José interpretavam o destino dos seres humanos "como um diálogo entre o poder dos perfumes e o poder das cores, e que propunham, a quem quisesse alcançar uma compreensão global do universo, submeter-se ao simultâneo ensino de Antúlio, Abel, Elias, Moisés e Maomé" (Martínez, 2004, p. 182). ${ }^{6}$

Por meio de seu narrador, o escritor insere a própria voz autobiográfica para dizer que ouviu pela primeira vez o nome de José López Rega quando tomou conhecimento do livro Astrologia esotéri$c a$, escrito por "El Brujo". O metatexto crítico de Martínez, assim, é praticado com uma parte, consideravelmente frequente, de intertexto citacional de apoio, referendando o indício paratextual que tem valor contratual (Cf. Genette, 1989, p. 18). Na mesma direção, fornece outros dados através de uma biografia reconstruída por membros do Clube de Correspondentes de Madri, na qual o esotérico aparecia

como integrante circunstancial da equipe de vigilância presidencial, por volta de 1950, e depois como um cabo disciplinado e ambicioso, a quem a lentidão das ascensões no escalão policial induziu a solicitar reforma em 1962. Sua

\footnotetext{
marcharme al extranjero. Desobedecí la advertencia y sólo tomé algunas precauciones. Diez días más tarde, estalló una segunda bomba y recibí amenazas más rotundas en el departamento donde vivía y en un restaurante donde estaba almorzando. Viajé a Francia, con la esperanza de regresar a las pocas semanas. Tardé nueve años en volver, sin embargo, con la salvedad de una fugaz semana en agosto de 1975 [...]"

5 “[...] al feligrés de las ciencias ocultas que vivía en Madrid desde hacía un año buscando la aprobación del General para su difusa doctrina espiritualista, que entretejía el iluminismo Rosacruz y la alquimia de Paracelso con los rituales brasileños de Umbanda."

6 "[...] como un diálogo entre el poder de los perfumes y el poder de los colores, y que proponían, a quienes quisieran alcanzar una comprensión global del universo, someterse al magisterio simultáneo de Antulio, Abel, Elías, Moisés y Mahoma."
} 
militância peronista parece iniciar aquele ano, quando se vinculou a alguns membros da loja maçônica Anael e instalou uma pequena imprensa nas proximidades da ponte ferroviária da rua Salguero, em uma das vias de acesso à Costanera Norte de Buenos Aires (Martínez, 2004, p. 182$183)^{7}$

Em 1963, López Rega havia imprimido alguns panfletos do peronismo clandestino e conquistado a confiança do major Bernardo Alberte, um dos herdeiros de Perón. Quando este mandou a esposa a Mendoza, em 1965, para apoiar o candidato a governador Ernesto Corvalán Nanclares, o então cabo reformado pediu a Alberte para servir como custódia de Isabel. "Conjetura-se que foi quando então a convenceu de seu desinteresse patriótico e obteve consentimento para colaborar com ela, como secretário ou assistente, no exílio em Madri” (Martínez, 2004, p. 183). ${ }^{8}$

Em 1971, praticamente todas as mensagens, telefonemas e pedidos de audiência dirigidos ao general passavam pela anuência do "Bruxo". Alguns peronistas, sabendo de tal vigilância, deixavam para entregar a correspondência quando se despediam do ex-mandatário, mas o secretário (a quem o narrador oferece voz) não raro tomava para si o envelope, "com o pretexto de que 'o General tem muitas coisas para atender e não convém abusar de sua saúde"” (Martínez, 2004, p. 184). ${ }^{9}$ A relação metatextual que se vai confirmando não prescinde de um elemento típico das narrativas ficcionais; trata-se da "metalepse" que, segundo Gérard Genette (2004), consiste em toda intrusão do narrador ou do narratário extradiegético no universo diegético (ou de personagens diegéticas num universo metadiegético etc.), ou inversamente.

Assim, as lembranças do escritor alcançam o protagonista no mês de junho de 1972, quando man-

\footnotetext{
7 "[...] como circunstancial integrante del equipo de vigilancia presidencial, hacia 1950, y luego como un cabo disciplinado y ambicioso, a quien la lentitud de sus ascensos en el escalón policial indujo a pedir retiro en 1962. Su militancia peronista parece arrancar aquel año, cuando se vinculó con algunos miembros de la logia Anael e instaló una pequeña imprenta cerca del puente ferroviario de la calle Salguero, en una de las vías de acceso a la Costanera Norte de Buenos Aires."

8 "Se conjetura que fue entonces cuando la convenció de su desinterés patriótico y obtuvo consentimiento para colaborar con ella, como secretario o asistente, en el exilio de Madrid."

9 "[...] con el pretexto de que 'el General tiene demasiadas cosas que atender y no conviene abusar de su salud'."
}

teve com ele um diálogo fugaz junto à Quinta 17 de Outubro. A ocasião permite a Tomás Eloy Martínez levantar uma hipótese a respeito da tolerância de Perón para com o mordomo, de cuja voz, outra vez destacada na narrativa, provém uma possível resposta: "“Eu sou o para-raios que detém todos os males enviados contra esta casa. Cada vez sou menos López Rega e cada vez sou mais a saúde do General"' (Martínez, 2004, p. 184). ${ }^{10}$

$\mathrm{O}$ narrador recorre a informes detidos em 1972 por um dos correspondentes de Madri para comunicar que o secretário do ex-presidente tinha um plano para transformar a Argentina num campo de cultivo mágico, a fim de transferir o peso político e o carisma de Perón a si mesmo e, posteriormente, fundar uma religião para o Terceiro Mundo, da qual seria ele o profeta e o pontífice. O escritor confirma essas pretensões místicas quando soma seu testemunho à história primeira que ele mesmo narra, e na qual sua presença é solicitada como narrador-personagem, se falarmos nos termos da teoria literária sobre a narrativa:

Não sou o único a quem se definiu em Madri como um fazedor de milagres, capaz de ressuscitar os mortos e ler os pensamentos alheios. Também não sou o único que começou a levá-lo a sério quando já era muito tarde e dispunha de uma cota de poder que somente lhe poderia ser arrebatada entre ruínas e dilaceramentos (Martínez, 2004, p. 185). ${ }^{11}$

Com uma ideologia esdrúxula, capaz de ir mais longe do que sonhava, o "milagreiro" deteve um poder que, contudo, não duraria muito tempo. A ambição por bens materiais, seu ponto frágil, é informada por Martínez a partir de correspondentes estrangeiros que, em 1970, reuniram dados sobre uma empresa de engarrafar água em Uruguaiana, cidade brasileira fronteiriça com a Argentina. A gravidade estaria no fato de ele impor ao produto o nome de Perón e sugerir que este recomendaria suas virtudes. Mais uma vez, a metalepse autobiográfica de Martínez confere autenticidade à narração:

\footnotetext{
10 'Yo soy el pararrayos que detiene todos los males enviados contra esta casa. Cada vez soy menos López Rega y cada vez soy más la salud del General.'”

${ }_{11}$ "No soy el único ante quien se definió en Madrid como un hacedor de milagros, capaz de resucitar a los muertos y leer los pensamientos ajenos. Tampoco soy el único que empezó a tomarlo en serio cuando ya era demasiado tarde y disponía de una cuota de poder que sólo se le podía arrebatar entre ruinas y desgarramientos."
} 
"Perguntei a López Rega sobre a veracidade daquela história. Devo dizer que a negou e atribuiu sua invenção, literalmente, ao ódio que lhe professavam "alguns inimigos bruxos" (Martínez, 2004, p. 186). ${ }^{12}$

O cotidiano do "Bruxo" no escritório da Gran Vía em Madri, o hábito da escrita (segundo ele, seu único prazer), a crença de que o destino da humanidade seria decidido por claves musicais, publicada em Astrología esotérica ao lado de conjeturas místicas sobre Perón, são dados antecedidos no texto pela breve, mas significativa, tomada biográfica na qual o testemunho de Martínez reitera o procedimento autobiográfico anteriormente indicado:

A impressão que me causou, quando o vi pela primeira vez, foi de qualquer maneira inferior ao personagem delirante e descarado que haviam prometido as fábulas madrilenses. Em vez do megalomaníaco e intrometido Rasputin anunciado por seus detratores, descobri uma espécie de sossegado bodegueiro de subúrbio, maciço como um touro, que carecia de escrúpulos na relação social e de senso do ridículo (Martínez, 2004, p. 186). ${ }^{13}$

A informação de que "El Brujo" teria utilizado o conhecimento adquirido nos arquivos e nas correspondências de Perón a fim de amedrontar peronistas que deixaram rastros escritos de sua deslealdade ou torpeza é atribuída a alguns de seus adversários. O autor-narrador, a partir dessa fonte, assegura: "O certo é que o domínio dessa enorme massa informativa, somada a sua infalível memória de policial bem adestrado, foi uma das chaves de seu poder político" (Martínez, 2004, p. 187). ${ }^{14}$ Participante assíduo das reuniões políticas da residência madrilense de Perón desde 1969, aproximadamente, o secretário acreditava em um Espírito Supremo que outorgaria poderes a alguns seres humanos e a outros, não. A esses, aos inimigos, caberia tratá-los com rigor, pois, de acordo com as convicções e as

\footnotetext{
12 "Pregunté a López Rega sobre la veracidad de aquella historia. Debo decir que la negó y que atribuyó su invención, literalmente, al odio que le profesaban 'algunos brujos enemigos'."

13 "La impresión que me causó, cuando lo vi por primera vez, fue de todos modos inferior al personaje delirante y cachafaz que habian prometido las fábulas madrileñas. En vez del Rasputín megalómano y entrometido que anunciaban sus detractores, descubrí más bien a una especie de sosegado almacenero de suburbio, macizo como un toro, que carecía de escrúpulos en la relación social y de todo sentimiento del ridículo."

14 "Lo cierto es que el dominio de esa enorme masa informativa, sumada a su infalible memoria de policía bien adiestrado, fue una de las llaves de su poder político."
}

palavras de López Rega, há alguns "homens que são escolhidos por Deus e outros, de cuja existência nem Deus sabe. Você com quem quer estar? Com a massa ou com o que amassa?" (Martínez, 2004, p. 187). ${ }^{15}$

É também considerado metaléptico esse enunciado que o "Bruxo" havia proferido acerca de si mesmo, consistindo em discurso secundário que empresta veracidade ao artigo por ele protagonizado, mas que integra uma coletânea na qual o papel de protagonista é ocupado em maior parte por Perón. O protagonismo do "Bruxo" se justifica na parte final do texto, que, integrando a coletânea $L a s$ memorias del general, é depois eliminada de sua reedição em Las vidas del general: memorias del exilio y otros textos sobre Juan Domingo Perón. Tal segmento levanta a possibilidade de que sua derrota fosse motivada pela cobiça e pelo excesso de fé em seus poderes individuais:

Antes de regressar à Argentina, Perón havia pregado que o país estava em ruínas, e que somente uma política de conciliação e unidade nacional poderia salvá-lo. Ao contrário, López Rega acreditou no isolamento do poder e na necessidade de que o país se colocasse a serviço de suas convicções. Foi o próprio Perón quem, de certo modo, derrubou-o de maneira póstuma, porque a imprensa, os partidos políticos, os sindicatos, os empresários e, sobretudo, o povo desesperado, se uniram e conciliaram para dizer-lhe basta. No entanto, somente quando se fizer o novo inventário das ruínas, haverá possibilidade de saber se essa voz de mando não teria se pronunciado tarde demais (Martínez, 1996, p. 144). ${ }^{16}$

A perspectiva de futuro volta a ser referida no artigo "El miedo de los argentinos" (Martínez, 2004, p. 189-208), também por intermédio da metalepse autobiográfica que opera como testemunho daqueles tempos durante os quais o povo argentino vivia triste e sem esperanças:

\footnotetext{
15 "[...] hombres que son elegidos por Dios y otros de los que Dios ni se entera que existen. ¿Usted con quién quiere estar? ¿Con la masa o con el que amasa?" 16 "Antes de regresar a la Argentina, Perón había predicado que el país estaba en ruinas, y que sólo una política de conciliación y unidad nacional podía salvarlo. A la inversa, López Rega creyó en el aislamiento del poder y en la necesidad de que el país se pusiera al servicio de sus convicciones. Fue el propio Perón quien, en cierto modo, lo derrocó de manera póstuma, porque la prensa, los partidos políticos, los sindicatos, los empresarios $y$, sobre todo, el pueblo desesperado, se unieron y conciliaron para decirle basta. Pero sólo cuando se haga el nuevo inventario de las ruinas, podrá saberse si esa voz de alto no se pronunció demasiado tarde."
} 
Somente quando se vem de longe pode-se saber até que ponto Buenos Aires já não é a mesma de três meses atrás. No começo, as razões não se explicam facilmente: as brumas e o sol escuro de agosto induzem a pensar que a tristeza do ar é outro fruto do inverno e que, provavelmente, quando as flores retornarem, renascerão também os velhos sinais de ventura que costumavam brilhar nas sacadas de Palermo ou nos sossegados domingos da avenida Forest (Martínez, 2004, p. 192). ${ }^{17}$

Nesse capítulo de Las vidas del general: memorias del exilio y otros textos sobre Juan Domingo Perón, o jornalista toma a realidade e os acontecimentos como reativações ou mutações do passado, exibindo os atores simbólicos centrais do peronismo e os fatos que os associam ao autoritarismo que marcou a sociedade argentina nos anos de 1970:

Nem todo este agosto é cruel, entretanto, porque o terror das sirenes noturnas se esfumou quase por completo da cidade. Disseram-me que os últimos de seus apitos foram ouvidos no dia 19 de julho [...] Contaram-me que já não se repetem histórias como a que eu vivi no dia 3 de novembro de 1974, na avenida Santa Fé, entre Canning e Malabia, quando um capanga anônimo protegido por dois Falcon (de uma cor da qual não posso me recordar) apontou com sua pistola a inofensiva têmpora do meu filho de três anos, desculpando-se mais tarde por estar "nervoso porque o senhor passou na metade de um procedimento" (Martínez, 2004, p. $192-193){ }^{18}$

Ao tratar do autoritarismo de Estado, o autor revisa o discurso historiográfico argentino, oferecendo visibilidade à falência da coletividade social num universo marcado por fortes antinomias, tais como peronismo e antiterrorismo, imperialismo

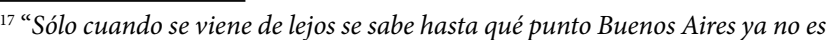
la misma que hace tres meses. Al principio no resulta fácil explicar las razones: las brumas y el sol oscuro de agosto inducen a pensar que la tristeza del aire es otro fruto del invierno y que, a lo mejor, cuando las flores vuelvan, renacerán también las viejas señales de ventura que solían brillar en los balcones de Palermo o en los sosegados domingos de la avenida Forest."

18 "No todo este agosto es cruel, sin embargo, porque el terror de las sirenas nocturnas se ha esfumado casi por completo de la ciudad. Me han dicho que el 19 de julio silbaron las últimas [...] Me han contado que no se repiten ya historias como las que viví el 3 de noviembre de 1974, en la avenida Santa Fe entre Canning y Malabia, cuando un matón anónimo protegido por dos Falcon (de un color que no puedo recordar) apuntó con su pistola la inofensiva sien de mi hijo de tres años, pretextando más tarde que éstaba nervioso porque usted pasó en mitad de un procedimiento"'
}

e nação, popular e antipopular. Se a violência que retornava como reação por parte dos guerrilheiros envolvidos com a luta armada não se mostrava nada desprezível, uma das obsessões dos governos militares argentinos entre as décadas de 1960 e 1970 foi a restauração da ordem e da autoridade a qualquer custo:

A violência do regime argentino não tinha, nem por vocação nem por definição, nenhum limite. A frase "isto não tem limites", expressando a admiração dos próprios executores pelas possibilidades sempre extremadas de seus respectivos aparelhos repressivos, demonstra cabalmente o processo de "fractalização" das instâncias de exercício repressivo, repetindo incessantemente a privatização e a antinomização que haviam caracterizado o processo político argentino em sua totalidade (Dellasoppa, 1991, p. 81). ${ }^{19}$

Sobre o processo especificamente argentino, afirma Guillermo O’Donnell (1988) que a visão da autoridade "não podia ser mais vertical, autoritária e renegadora da autonomia daqueles que pretendeu submeter e não conseguiu, apesar do tom paternalista com que revestia seus argumentos, ocultar a imensa violência, não apenas física, sobre a qual se sustentava" (p. 40). ${ }^{20} \mathrm{O}$ artigo "El miedo de los argentinos" (Martínez, 2004, p. 189-208) permite notar a postura ética dos cidadãos diante da violência quando informa sobre a "lista negra" do jornalismo, divulgada em 1973, os fuzilamentos dos presos políticos e os inúmeros casos de crueldades, desaparecimentos, invasões de domicílio e torturas. A necessidade de contar esses fatos desde a primeira pessoa apresenta-se como um deslocamento do narrador-observador, um modo através do qual Martínez, como investigador, testemunha e personagem, recorre em simultâneo às técnicas do jornalismo investigativo e à metalepse, recurso típico da narrativa literária:

\footnotetext{
19 "La violencia del régimen argentino no tenía, por vocación y por definición, ninguno límite. La frase 'esto no tiene límites', expresando la admiración de los propios ejecutores por las posibilidades siempre plus ultra de sus respectivos aparatos represivos, muestra cabalmente el proceso de 'fractalización' de las instancias del ejercicio represivo, repitiendo incesantemente la privatización y antinomización que tenían caracterizado el proceso político argentino global." 20 “[...] no podía ser más vertical, autoritaria y negadora de la autonomía de aquellos que pretendió someter y ni consiguió, a pesar del tono paternalista con que revestía sus argumentos, ocultar la inmensa violencia, no sólo física, sobre la que se sustentaba."
} 
Sempre desconfiei do jornalista que abusa da escritura em primeira pessoa porque, em geral, está acreditando que sua aventura privada é mais interessante do que o curso da história. Entretanto, advirto desolado que, nos últimos meses, contar um fato à distância torna-se cada vez um ato menos sincero porque nós, jornalistas, viemos perdendo nossa fértil qualidade de testemunhas para nos convertermos em protagonistas de uma esmagadora odisseia coletiva. Peço então que não me repreendam se, nesta história sobre o medo dos argentinos, introduzo a narração de meu próprio medo, aliviado em saber que, pelo menos, não difere demasiadamente de outras vicissitudes. A primeira pessoa é útil quando se perdeu a fé na eficácia das palavras, como ocorre com a maioria de todos nós (Martínez, 2004, p. 194). ${ }^{21}$

Em repúdio à omissão da sociedade civil diante da violência de Estado, Martínez acusa a amnésia social, o destino real dos "ameaçados", o silêncio e as cumplicidades dos meios de comunicação. Como um dos tantos jornalistas perseguidos pela organização terrorista de extrema direita Triple A, comparte desde o exílio um olhar de responsabilidade com os destinos pátrios, pois o ato de recordar se convertia em alerta para o futuro:

A memória arruinada é uma epidemia frequente entre os argentinos, mas agora se torna visível o fato de essa forma de esquecimento, que reserva a amnésia para certas vítimas, constituir um agravo às outras vítimas e até mesmo um encobrimento dos outros assassinatos. É o esquecimento do que ocorreu ontem mesmo, do que ainda hoje está ocorrendo (Martínez, 2004, p. 195). ${ }^{22}$

$\mathrm{O}$ autor-narrador continua a declarar a falta de informação do povo argentino sobre o descalabro econômico e sobre os riscos que as pessoas corriam

\footnotetext{
${ }_{21}$ "Siempre desconfié del periodista que abusa de la escritura en primera persona, porque por lo general está creyendo que su aventura privada es más interesante que el curso de la historia. Pero advierto con desolación que en los últimos meses resulta cada vez menos sincero contar un hecho a distancia, porque los periodistas hemos ido perdiendo nuestra fértil calidad de testigos para convertirnos en protagonistas de una abrumadora odisea colectiva. Ruego que no se me reproche, entonces, si en esta historia sobre el miedo de los argentinos introduzco la narración de mi proprio miedo, con el alivio de saber que al menos no difiere demasiado de otras vicisitudes. La primera persona es útil cuando se ha perdido la fe en la eficacia de las palabras, como ocurre con la mayoría de nosotros."

22 "La mala memoria es una epidemia frecuente entre los argentinos, pero ahora está a la vista que esta forma de olvido unilateral que reserva la amnesia para ciertas víctimas constituye un agravio a las otras víctimas $y$ hasta un encubrimiento de los otros asesinatos. Es el olvido de lo que ocurrió ayer mismo, de lo que aún hoy está ocurriendo."
}

se viessem a falar sobre o que acontecia na sociedade rioplatense. Naquele momento, em que o medo se fazia perceptível na censura às programações do cinema ou da televisão, a memória coletiva dos argentinos guardou uma série de frases expressivas de temores e de saturações:

[...] a de Víctor Bruno, substituto de Brandoni na secretaria geral de Atores, no dia 13 de maio: "Até quando devemos esperar para que o governo desmascare os assassinos da Triple A?"

a de Ricardo Balbín, no dia 15 de maio, durante o almoço da Asociación de la Prensa Extranjera: “Já vivi o necessário, de modo que, quem tiver vontade de se cobrar comigo, que se cobre, porque não haverei de sentir saudades dos anos que estão por vir".

a do senador Carlos H. Perette, no Senado, dia 21 de maio, ao condenar o assassinato do jornalista Jorge Money: "O que se pretende com tudo isso? Primeiro, criar o desânimo argentino? Segundo, semear o terror no país? Terceiro, imolar o direito ao livre pensamento? Quarto, criar o desprezo pela vida humana?"' (Martínez, 2004, p. 202) ${ }^{23}$

Outras frases aparecem como o lado reverso do mesmo terror, a exemplo daquela que o coordenador de imprensa do Ministério de Bem Estar-Social, Juan Carlos Rousselot, proferiu no dia 2 de junho em entrevista para a revista Las Bases, reproduzida por La Opinión:

Quem que não conhece López Rega provavelmente não haverá de entender a razão de ele ser tão querido por aqueles que o conhecemos [...] é importante que todos compreendam que, em José López Rega, há um homem desprendido completamente de todo e qualquer interesse que não tenha nada a ver com a realização da missão que está cumprindo em benefício de seu país (Martínez, 2004, p. 202). ${ }^{24}$

\footnotetext{
23 "[...] la de Víctor Bruno, reemplazante de Brandoni en la secretaría general de Actores, el 13 de mayo: ¿¿Hasta cuándo debemos esperar para que el gobierno desenmascare a los asesinos de la Tripe A?'.

la de Ricardo Balbín, el 15 de mayo, durante la comida de la Asociación de la Prensa Extranjera: 'Ya he vivido lo necesario, de manera que quien tenga ganas de cobrarse conmigo que se cobre, porque no he de extrañar los años que vienen'.

la del senador Carlos H. Perette, en el Senado, el 21 de mayo, al condenar el asesinato del periodista Jorge Money: ¿Qué se pretende con todo eso? Primero, ¿crear el desaliento argentino? Segundo, ¿sembrar el terror en el país? Tercero, ¿inmolar el derecho al pensamiento libre? Cuarto, ¿crear el desprecio por la vida humana?"'

24 "Aquel que no conoce a López Rega probablemente no entiende por qué quienes lo conocemos lo queremos tanto [...] es importante que
} 
Mais tarde, "El Brujo" alcançava seu dia de glória, precisamente a 20 de junho, quando, ao regressar do Brasil depois de gerir algumas operações imobiliárias no estado brasileiro de Santa Catarina, era recebido pela presidenta Isabel Perón no aeroparque de Buenos Aires com todas as fanfarras somente dignas de um chefe de Estado. Depois desse momento, sua imagem passou a ser considerada a de um amo nacional, o que lhe possibilitou depositar ainda mais fé em sua onipotência, e esquecer o constante cheiro de pólvora que impregnava os ares argentinos de agonia: "Retornamos com ânimo e força renovadora para jogar duro com quem não quiser colaborar com a pátria e, para aqueles que tiverem a cabeça dura, haveremos de encontrar uma clava adequada a sua dureza" (Martínez, 2004, p. 203). ${ }^{25}$

Martínez acrescenta que, quem recorresse aos jornais daquelas semanas, como Brandoni e ele mesmo, iria descobrir que La Opinión era uma voz insolente e solitária:

López Rega vivia seu momento mais glorioso quando La Opinión publicou, no dia 19 de junho, um suplemento intitulado: "Treinta días contra la libertad de expresión". E ele ainda era o principal conselheiro da Presidência quando, a 6 de julho, apareceu em primeira página um artigo de Heriberto Kahn que revelava as conexões, estabelecidas por fontes do exército, entre o ministro López Rega e os assassinos da Triple A (Martínez, 2004, p. 204). ${ }^{26}$

O jornalista finaliza o capítulo numa espécie de relação paratextual ao destacar uma das palavras que figuram em seu título - o medo - um dos maiores inimigos do ser humano:

Agosto é - já se sabe - o mês mais longo e também o mais cruel. Quando acabar, daqui a três domingos, nenhum de nós será mais o mesmo:

todos comprendan que en José López Rega hay un hombre desprendido completamente de todo interés que no sea realizar la misión que está cumpliendo en beneficio de su país."

25 "Hemos retornado con ánimo y fuerza renovadora para darles duro a quienes no quieren colaborar con la patria, y a los que tengan la cabeza dura les vamos a encontrar una maza adecuada a su dureza."

26 "Vivía López Rega su hora más gloriosa cuando La Opinión publicó, el 19 de junio, un suplemento titulado: 'Treinta días contra la libertad de expresión'. Y era todavía el principal consejero de Presidencia cuando, el 6 de julio, apareció en primera página un artículo de Heriberto Kahn que revelaba las conexiones, establecidas por fuentes del Ejército, entre el ministro López Rega y los asesinos de la Triple A." andaremos ainda tateando em busca da fé que nos amputaram, da alegria que nos macularam, da vida que jamais recuperaremos. Ainda nos restará como consolo, todavia, o país enorme ao qual nenhuma das infinitas corrupções $[. .$.$] pôde$ derrocar por completo. [...] Porém, agora que deixamos para trás tanto desamparo, ao menos sabemos que qualquer tempo futuro haverá de ser melhor (Martínez, 2004, p. 208). ${ }^{27}$

O capítulo denominado "Perón y los nazis" (Martínez, 2004, p. 209-238), datado de março de 1984, quando o escritor trabalhava em sua narrativa romanesca La novela de Perón, versa sobre o fluxo de nazistas que emigrou à Argentina durante o primeiro governo peronista. Em forma de ensaio acadêmico, busca explicar como essa migração foi aberta e oficialmente administrada pelo Estado, uma vez que o país havia se convertido em principal refúgio dos criminosos de guerra alemães e croatas na América do Sul. O texto original foi escrito em inglês e lido no Woodrow Wilson International Center for Scholars, que acolhia Martínez como romancista residente desde setembro de 1983. Discutido em sessão aberta que durou toda uma manhã, depois corrigido e publicado como documento de trabalho do Wilson Center, seria fartamente citado uma década mais tarde, quando Carlos Menem prometeu trazer à luz os arquivos dos nazistas na Argentina, constituindo umas das primeiras investigações sobre o tema, que posteriormente contaria com maior abundância documental.

Ocorre que, cerca de dez anos após a queda de Perón, em 1955, a migração nazista à Argentina continuava sendo um rumor impreciso. Somente nos anos 1970 o ex-presidente confirmou ter dado refúgio a milhares deles, por um "senso de humanidade", ao mesmo tempo que permitiu o ingresso de cinco mil croatas ameaçados de morte pelo marechal Tito, da então Iugoslávia. O tema nazista seria novamente aludido no relato autobiográfico aqui utilizado como intertexto, Yo, Juan Domingo Perón, editado na Espanha por um trio de jornalistas, e a

\footnotetext{
27 "Agosto es -ya se sabe - el mes más largo y también el más cruel. Cuando acabe, dentro de tres domingos, ninguno de nosotros será el mismo: andaremos todavía a tientas en busca de la fe que nos amputaron, de la alegría que nos ensuciaron, de la vida que jamás recuperaremos. Pero nos quedará, como consuelo, el país enorme al que ninguna de las infinitas corrupciones [...] pudo derribar por completo. [...] Pero ahora que hemos dejado atrás tanto desamparo, sabemos al menos que cualquier tiempo futuro será mejor."
} 
tomar como base uma série de gravações confiadas a uma dama que desfrutava da intimidade da família:

A princípio, a narração parece aquilo que, em argentino, chamamos de guitarreo, uma fabricação de relatos. Perón afirma que muitos dos refugiados alemães chegaram às costas argentinas "nos submarinos U-530 e U-532" a meados de julho de 1945 e um mês depois. Dois submarinos alemães se renderam nessas datas às autoridades navais argentinas, em Mar del Plata. Um deles era o U-530; a denominação do outro era, em verdade, U-977. Em nenhum dos dois havia técnicos famosos nem criminosos de guerra. As tripulações foram escrutadas com excepcional cuidado pelo Serviço de Inteligência Naval dos Estados Unidos, sem dar guarida a nenhuma das lendas que então circulavam, incluindo a mais extravagante de todas: que a bordo viajavam Adolf Hitler e Eva Braun. O U-530 levava 54 homens cuja idade média era de 23 anos; o capitão tinha 25 . O U-977 tinha uma tripulação levemente menor, 48 homens, mas as idades eram as mesmas (Martínez, 2004, p. 224). ${ }^{28}$

Ainda no relato autobiográfico, inserido no ensaio que não deixa de recorrer à biografia de Perón, este detém-se apenas no embarque dos "alemães úteis", contatados por funcionários argentinos comissionados na Suíça e na Suécia com tal objetivo. $\mathrm{O}$ general insiste que as migrações formavam parte de uma competição com a União Soviética e com os Estados Unidos, destinada a captar gênios. No final do texto, Martínez acrescenta que talvez fosse exagero supor que a barbárie da última ditadura militar argentina tivesse influência de algo tão remoto como a migração nazista ocorrida entre os anos de 1947 e 1950 . No entanto,

as semelhanças entre os métodos repressivos dos dois regimes são tão vastas que não poderiam obedecer ao acaso. O exercício da tortura e da escravi-

\footnotetext{
28 "Al principio, la narración parece lo que en argentino se llama 'un guitarreo', una fabricación de relatos. Perón afirma que muchos de los refugiados alemanes llegaron a las costas argentinas 'en los submarinos U-530 y U-532', a mediados de julio de 1945 y un mes después. Dos submarinos alemanes se rindieron en esas fechas a las autoridades navales argentinas, en Mar del Plata. Uno era el U-530; la denominación del otro era, en verdad, U-977. En ninguno de los dos había técnicos famosos ni criminales de guerra. Las tripulaciones fueron escrutadas con excepcional cuidado por el Servicio de Inteligencia Naval de los Estados Unidos, sin encontrar asidero a ninguna de las leyendas que circulaban por entonces, incluyendo la más extravagante de todas: que a bordo viajaban Adolf Hitler y Eva Braun. El U-530 llevaba cincuenta y cuatro hombres, cuya edad promedio era de veintitrés años; el capitán tenía veinticinco. El U-977 tenía una tripulación ligeramente menor, cuarenta y ocho hombres, pero las edades eran las mismas."
}

dão contra inocentes ou adversários que já não resistiam, a concepção da guerra como extermínio, o plágio dos campos de concentração, das fossas comuns, dos fornos crematórios, não são meras paródias subdesenvolvidas de uma história atroz. São a lição pontual de discípulos alienados (chamem-se eles Videla, Massera, Camps, Chamorro, Viola ou Galtieri) pelo legado que deixaram inconcluso os mestres do Terceiro Reich (p. 237). ${ }^{29}$

Assim, no amplo cenário psicossocial contemplado pelos artigos de cunho jornalístico e memorialístico ora analisados, a migração nazista à Argentina opera como fato de ligação entre as ditaduras sanguinárias das décadas de 1960-1970 e o peronismo que, gestado a partir do golpe de Estado de 1943, contaria com o apoio dos católicos, de grande fração dos militares e de uma ampla maioria do operariado e da pequena classe média urbana. Por sua vez, a figura biográfica de José López Rega funciona como um dos elos da corrente que obtém a façanha de reunir, sob o manto do peronismo nos anos 1970, a extrema direita, representada por organizações como a Triple A, com a qual o "Bruxo" tinha notórias ligações, e a extrema esquerda, capitaneada pelos guerrilheiros abrigados no grupo Montoneros.

A projeção da biografia de López Rega nas memórias e na biografia de Perón, dentre outros fatores, possibilita notar nos textos estudados algumas das distintas articulações e interseções com o gênero biográfico e com narrativas de narrativas de aspecto biográfico. A voz autobiográfica de Tomás Eloy Martínez conjuga-se a esse "espaço biográfico" (Cf. Arfuch, 2010) quando o próprio jornalista descreve episódios curiosos que envolveram a escritura e a reescritura dos artigos contemplados tanto por Las memorias del general, quanto por sua reedição como Las vidas del general: memorias del exilio y otros textos sobre Juan Domingo Perón. Esses textos, nos quais a memória joga papel destacado, colocam em relevo os frágeis limites que assinalam

\footnotetext{
29 "[...] las semejanzas entre los métodos represivos de los dos regímenes son tan vastas que no pueden obedecer al azar. El ejercicio de la tortura y de la esclavitud contra inocentes o adversarios que ya no se resistían, la concepción de la guerra como exterminio, el plagio de los campos de muerte, de las fosas comunes, de los hornos crematorios, no son meras parodias subdesarrolladas de una historia atroz. Son la puntual lección de discípulos enajenados (llámense Videla, Massera, Camps, Chamorro, Viola o Galtieri) por el legado que dejaron inconcluso los maestros del Tercer Reich."
} 
os discursos (auto)biográficos. Desse modo, além de apresentar o ex-presidente argentino como sujeito histórico e personagem de si mesmo, por intermédio de estilhaços biográficos e das memórias que, devido à necessidade de confronto com a história, vêm a ser classificadas como (des)memórias, o autor nos entrega, em sua escrita jornalística, mas também literária, autobiográfica, biográfica e memorialística, dois modos de representar a Argentina: através do silêncio da história e do desejo de fazer a história acontecer.

Debruçados sobre a Argentina populista e ditatorial, os relatos memorialísticos de Perón se fazem acompanhar das perspectivas biográficas, dirigidas à vida individual do general, seu protagonista, e do "Bruxo", personagem secundária que ascende a principal, assim como ocorreu com o ser histórico no qual é baseada. Aliados à necessidade de suplementação do ato memorialístico pela investigação histórica e jornalística, bem como a uma constante evocação dos tempos de escritura das narrativas, esses fatos nos indicam que as escritas da memória não se voltam apenas às relações entre indivíduo e sociedade, mas também aos vínculos passado-presente-futuro.

Nessa confluência, revigorada por uma série de relações arquitextuais, hipertextuais, intertextuais, metatextuais e paratextuais, a figura de um dos políticos mais emblemáticos da América Latina serve para que Martínez tente ele também explicar o fracasso de um projeto de transformação econômica e política da Argentina, e seus lamentáveis desdobramentos, num tempo designado como "era dos extremos e das catástrofes" (Cf. Hobsbawm, 1995; Seligmann-Silva, 2003). As intrusões autobiográficas do sujeito produtor em vários dos artigos por ele escritos configura um tipo de metalepse que tipifica especial, mas não exclusivamente, as narrativas literárias. $\mathrm{O}$ metatexto crítico autentica as configurações que o ficcionista e jornalista argentino havia estabelecido para sua obra - as (des)memórias de Perón ao lado de outros textos; a vida do general junto de outras vidas -, tomando a forma de uma metalepse que "está no núcleo íntimo de tudo o quanto cremos poder dizer ou pensar a respeito de nós mesmos, se for verdade pois é verdade - que je sempre é também um outro" (Genette, 2004, p. 129). ${ }^{30}$

\section{Referências}

ARFUCH, Leonor. O espaço biográfico: dilemas da subjetividade contemporânea. Tradução de Paloma Vidal. Rio de Janeiro: EdUER, 2010.

CRASSWELlER, Robert. Perón y los enigmas de la Argentina. Buenos Aires: Emecé, 1988, p. 248.

DELLASOPPA, Emilio E. Reflexões sobre a violência, autoridade e autoritarismo. Revista USP, p. 81, mar./abr./ maio. São Paulo: Universidade de São Paulo, 1991.

GENETTE, Gérard. Metalepsis: de la figura a la ficción. Traducción por Luciano Padilla López. Buenos Aires: Fondo de Cultura Económica, 2004.

GENETTE, Gérard. Palimpsestos. Madri: Altea; Taurus; Alfaguara, 1989.

HOBSBAWM, Eric. A era dos extremos, o breve século XX (1914-1991). Tradução de Marcos Santa Rita. São Paulo: Companhia das Letras, 1995.

MARTÍNEZ, Tomás Eloy. Las memorias del general. Buenos Aires: Planeta, 1996.

La novela de Perón. Buenos Aires: Planeta, 1985.

Las vidas del general. Buenos Aires: Aguilar; Altea; Taurus; Alfaguara, 2004.

Santa Evita. Buenos Aires: Biblioteca del Sur; Planeta, 1995.

NEIBURG, Frederico. Os intelectuais e a invenção do peronismo. São Paulo: Edusp, 1997, p. 14-15.

O’DONNELL, Guillermo. Argentina: a macropolítica e o cotidiano. Lua Nova, v. 4, n. 2, p.40, São Paulo, abr./jun. 1988.

SELIGMANN-SILVA, Márcio (Org.). História, memória, literatura - o testemunho na era das catástrofes. Campinas: Editora da Unicamp, 2003.

Artigo Submetido:15/02/2013

Artigo Aprovado:13/09/2013

30 "[... está en el núcleo intimo de todo cuanto creemos que podemos decir o pensar respecto de nosotros mismos, si es verdad - pues es verdad - que je 